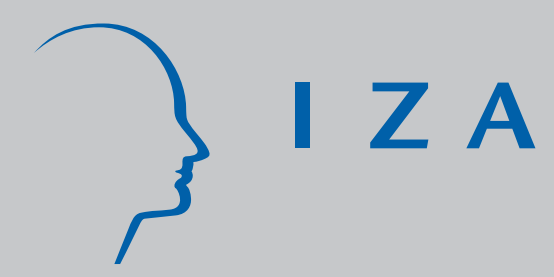

IZADP No. 2224

The Location of Immigrants at Retirement: Stay/Return or 'Va-et-Vient'?

Augustin de Coulon

François-Charles Wolff

July 2006 


\title{
The Location of Immigrants at Retirement: Stay/Return or 'Va-et-Vient'?
}

\author{
Augustin de Coulon \\ NRDC, Institute of Education, \\ CEP, London School of Economics \\ and IZA Bonn
}

\section{François-Charles Wolff \\ LEN, University of Nantes}
Discussion Paper No. 2224
July 2006

IZA

P.O. Box 7240

53072 Bonn

Germany

Phone: +49-228-3894-0

Fax: +49-228-3894-180

Email: iza@iza.org

\begin{abstract}
Any opinions expressed here are those of the author(s) and not those of the institute. Research disseminated by IZA may include views on policy, but the institute itself takes no institutional policy positions.

The Institute for the Study of Labor (IZA) in Bonn is a local and virtual international research center and a place of communication between science, politics and business. IZA is an independent nonprofit company supported by Deutsche Post World Net. The center is associated with the University of Bonn and offers a stimulating research environment through its research networks, research support, and visitors and doctoral programs. IZA engages in (i) original and internationally competitive research in all fields of labor economics, (ii) development of policy concepts, and (iii) dissemination of research results and concepts to the interested public.
\end{abstract}

IZA Discussion Papers often represent preliminary work and are circulated to encourage discussion. Citation of such a paper should account for its provisional character. A revised version may be available directly from the author. 


\section{ABSTRACT}

\section{The Location of Immigrants at Retirement: Stay/Return or 'Va-et-Vient'?}

In this paper, we investigate the location choice of immigrants when retiring. In a context where labour considerations no longer matter, the location decisions are expected to depend not only on a comparison of standard-of-living between the origin and host countries, but should also be affected by the strength of family relationships. Assuming that migrants derive some satisfaction from contact and visits with other family members, we suggest that migrants may choose a third type of migration move beyond the standard stay/return decision called the 'va-et-vient', where individuals choose to share their time across the host and the origin country. In the empirical analysis, we investigate the determinants of the location intention when retiring using a recent data set on migrants currently living in France. We find that the migrant's choice is significantly related to the location of other family members and that those determinants vary with respect to the different preferred choices.

JEL Classification: J26, O15, R23

Keywords: return migration, retirement, family interactions

Corresponding author:

Augustin de Coulon

London School of Economics

Houghton Street

WC2A 2AE London

United Kingdom

E-mail: a.de-coulon@Ise.ac.uk

\footnotetext{
* We are indebted to Christian Dustmann, Alan Manning, Arnaud Chevalier and Olivier Guillot for very helpful comments and suggestions. We also thank participants of the Centre for Economic Performance (London School of Economics) annual meeting at Stoke Rochford and the European Society for Population Economics Annual Conference in Bergen, and seminar participants at Nancy University. Any remaining errors are ours.
} 


\section{Introduction}

Immigrants' decision to return to their home country has attracted much attention over the previous decade (see Dustmann, 2001). Until now, the literature has only investigated the returns of working age immigrants. This paper brings some new findings on the optimal location decision of immigrants at the time of their retirement. In particular, we document a previously unknown location strategy beyond the traditional stay/return choice. We observe that around a quarter of immigrants in our comprehensive data set are willing neither to return home nor to stay in the host country when retiring, but they intend to spend a fraction of the year in each country. The data set being collected in France, we call this strategy the 'va-et-vient'.

Some facts lead us to think that the importance of this alternative strategy may not be confined to our data set. Importantly, immigrants living in France who decide to retire can claim their full pension benefits in the chosen country of living. In fact, as much as $8 \%$ of all pensions benefits in France are paid to retirees who lives abroad (CNAV, 2002). So, the French pension system does not appear to provide any incentives to choose to conduct a 'va-et-vient' rather than to return in the home country or to stay in the host country. Recent evidence suggests that immigrants' decision of location is certainly not restricted to a simple stay versus return choice.

In Germany, Constant and Zimmermann (2003) find that as much as $60 \%$ of immigrants interviewed in the German Socio-Economic Panel (GSOEP) are multiple movers, who at one time during their stay in Germany choose to spend a period in the home country and then come back to the host country ${ }^{1}$. Other evidence suggests that a substantial proportion of Indian and Taiwanese immigrants in the US tend to commute with their origin country for investment purpose (ILO, 2003). Sociologists have documented that a third of a sample of Italians and Spanish retired immigrants in Switzerland choose to share their time between the host and the origin country (Bolzman et al., 1993). Other evidence in Sweden, in the US and the UK points to a related pattern observed amongst retirees who can afford to spend part of the year in "warmer" regions at the time of retirement (Gustafson, 2001, Hogan and Steinnes, 1998, King et al., 1998).

With the bulk of unskilled immigrants arrived in the main European host countries such as Germany, France and the UK during the 1960's and 70's, we expect those immigrants to take their retirement soon. The optimal location of retired immigrants could pose a challenge to policy makers of both the host and the origin countries if we imagine the case of a sudden return of large waves of retired immigrants in their home country. Health expenses would be alleviated in the host and increased in the origin country. And aggregate consumption would increase in the

\footnotetext{
1 The use of a panel data set may lead to measurement errors, owing in particular to selective attrition. It is certainly very difficult to track a migrant who decides to return to the origin country and then to come back in the host country.
} 
origin and decrease in the host. Few is however known on the individual location choice arising for immigrants at retirement. This paper sets to provide a first investigation of such a choice.

Our paper is related to the analysis of Konrad et al. (2002), where the optimal location decision of children is primarily determined by the location of siblings with the perspective of caring for parents. Unlike these authors, however, we focus on the location decision of parents when retiring. Another main difference with this paper is their focus on a "geography of the family" living in the same country. Our paper is set in the international rather than the internal migration framework. We do consider the effect of taste for living in different country that matter for the location at retirement. Finally, by studying immigrants' location at retirement, our paper implicitly relies on models of lifecycle migration where individuals move for a limited duration with the intention to return to the origin country (Djajic and Milbourne, 1988).

Dustmann (2003) considers both realised and intended return decision of immigrants in their home country, and introduces the role of young children as a main determinant. He finds support for a story where children cause return decisions of parents using the randomness of the sex of children as an identifying strategy. The empirical results are consistent with a model where parents care for the future of their children, those considerations being different for sons and daughters. The home country is judged more beneficial for daughters, while the host country is preferred for boys. Parents favour more the cultural environment in the origin country for daughters whereas they value more the economic prospects offered in the host country for sons. Implicitly, in this framework, parents are the only decision makers in the location decision, an assumption implied by the time frame investigated, i.e. the working life. For older parents at retirement, however, this assumption has to be relaxed.

Empirically, we investigate the main determinants of the 'va-et-vient' choice in comparison with the decision to return and to stay. Using a similar identifying strategy as Dustmann (2003), we find that the actual location of children, in the host or the origin country, matters much more for the return intention than for the 'va-et-vient'. We also investigate the importance of other family ties on the respondents location at retirement (namely their parents, siblings, and other family members), both for the 'va-et-vient' and the return. The data shows that the 'va-et-vient' is more often chosen by immigrants originating from other countries than Northern Europe and that the return is more frequent for immigrants originating from Southern Europe and from Central and the South of Africa.

The remainder of the paper is organised as follows. In Section 2, we propose a discussion of the possibility of a 'va-et-vient' choice. In Section 3, we describe our detailed data set which focuses on older immigrants living in France and discuss further the importance of the 'va-et- 
vient' decision. In Section 4, we first show that the location of the family members is strongly related to the preferred location at retirement and then discuss of the potential endogeneity of the actual location of children. Concluding comments are in Section 5.

\section{Theoretical background}

The decision to return for immigrants is most probably related in many ways to the present and future location of their children. Only few papers, however, have studied this linkage.

The most noticeable exception is the work of Dustmann (2003), who studies the return of parents who have young children and assumes that the parents are the only decisions makers. The location choice of the parents is based on an intertemporal comparison of indirect utility in the host and the origin country. The utility depends on their own consumption and their child's one, on preference parameters for the home and the origin country, and on their degree of altruism towards their children. The preference parameters are central in the model as they shed light on how parents value their children well-being in the host and the origin country. If parents consider the home country environment more beneficial for the children, this may compensate for other more favourable conditions in the host country such as higher income (which is part of the budget constraint).

The main testable implication of this model is that parent may consider differently the relative home and host country benefit for sons and daughters. For immigrants originating from traditional cultural environment, in particular, one can assume that the host country environment is perceived more beneficial for sons in terms of earnings and career potential, but less so for daughters. Conversely, the origin country may be considered as more beneficial for the daughters' future in terms of marriage agreements, and lifestyle.

Despite of its interest, this model cannot be used as such to investigate our problem. At the time of the retirement of parents, most children are adults and their location decision would certainly have to be modelled separately. An appropriate framework would need to integrate the interdependent decisions of parents and children, also allowing for revisions of both intentions following change in individual health, employment status and labour market conditions in the host and origin country. As such a framework is beyond the scope of our contribution, we instead rely on a formal discussion of why parents may rely on a 'va-et-vient' strategy in a context where their children are young adults. 
A possibility to explain the 'va-et-vient' decision is to assume that parents derive utility from attention or care provided by their children, as in Konrad et al. (2002) ${ }^{2}$. Several studies have shown that the upstream transfers were strongly decreasing with the distance separating both generations (Jellal and Wolff, 2002, Sloan et al., 2002). So, when both parents and children live in the same place, the number of visits and contact should be much more important and this increases the benefits for the parents to stay in the country where their own children are living.

Of course, the need for upstream attention cannot be the sole argument to explain the parental location and economic benefits are also expected to matter. Assume for instance that the pension payment does not differ whether individuals are located in the host or the origin country after return. Thus, owing to different purchasing power in France and in the origin country, a higher value of income should be associated with the origin country. This can lessen the incentive to stay in France even if the children are living there, so that location at retirement would be given by a trade-off between financial aspects and family considerations.

In this setting, we argue that parents may choose a new strategy beyond the stay/return choice, which consists in sharing their time across the host and the origin country. Incentive to rely on this strategy would be given by the opportunity to minimise the cost of separation from the closed family and in particular the children. Obviously, it can only be chosen at retirement when the location is no more constrained by the job exerted. Indeed, having a paid job prevents from living in different countries over the year.

When all the children are living in the host country, parents may be expected to stay in that country at retirement if the marginal benefit derived from family relationships is greater than the marginal benefit related to greater value of income in the origin country ${ }^{3}$. Now, if children are spread across the host and the origin country, then the choice of a 'va-et-vient' strategy is more likely to occur. In so doing, elderly parents will certainly receive more attention from all their children. Sharing time between the host and the source country allows having frequent contact with children living in the host country while staying in that country, and also frequent contact with children living in the origin country when parents choose to temporarily return.

Note that family relationships are not restricted to interactions between children and their parents. Indeed, parents may also enjoy having contact with other family members, whose location may again be either in the host or in the origin country. Nevertheless, we believe that the further away from the nuclear family the individuals are, the less these interactions matter. This hierarchy may be explained by the evolutionary theory of sympathy between relatives described in

\footnotetext{
${ }^{2}$ A convenient way to include this behaviour is to simply assume that the number of contact enters positively into the utility function of parents.

3 This can be the case as interaction with children is a service without any direct substitute (Ehrlich and Lui, 1991, Laferrère and Wolff, 2006).
} 
Bergstrom (1996). Following the theory of kin selection given by Hamilton's rule, one can define a coefficient of relationship between kin such that children and parents matter the most, then siblings, then grand-parents, uncles, aunts, less close friends and acquaintance having ultimately the lower weight.

In our previous discussion, an implicit assumption was that children location decision was made prior to the location decision of parents at retirement. Konrad et al. (2002) consider a more general model of family location where siblings are altruistic towards the parents and both parents and children are allowed to choose where to locate, depending on where the parents and siblings are located. In that case, the firstborn child's location decision should influence the location choice of latter born children. Locating further away from the parents allows shifting part of the burden of providing parental care. The 'va-et-vient' choice is not a strategy in this model, which is more appropriate to explain a "geography of the family" rather than the location of immigrants at retirement.

From an empirical viewpoint, it matters to know whether in migrants' families, children and other family members make independent location choices. If this assumption is relevant, this means that the locations of other family members may be introduced as exogenous explanatory variables in the parental location equation. For instance, if parents are around 60 and their adult children are about 30, have a paid job and own a dwelling in the host country, the latter are certainly unlikely to move. Nevertheless, it may be that younger children entering their adult life decide to live in the same country as the one chosen by their parents for retirement.

This paper is set to investigate the location intention of immigrants currently living in the host country and not yet retired. They are three main types of bias that may potentially prevent a causal relationship between the contemporary location of children and the intended location of parent for retirement. First, parents and children may take location decisions simultaneously. This would occur for instance if children locate according to how they expect their parents to react to these choices. Also, parents may try to instill in their children the desire to choose the same location that they will choose when retiring. Second, unobserved heterogeneity may impact the effect of the child location on the parental decision. This occurs if there are some unobserved common factors that influence both the location of children and the intended one of parents at retirement ${ }^{4}$. Finally, measurement errors may bias the observed correlation. This would be the case if the location of children observed in the survey is not permanent and change subsequently until the parents retire.

\footnotetext{
${ }_{4}^{4}$ This is the case of family altruism, which remains unobserved by the econometrician. Altruism is important as children will provide more upstream transfers and attention if they are more altruistic towards their parents, while altruistic parents will also experience more satisfaction from their children's contact.
} 
As our empirical analysis relies on cross-sectional data, we are unable to properly deal with unobserved heterogeneity and measurement error in our econometric analysis ${ }^{5}$. However, we are able to control for the potential bias due to simultaneity issues. We will devote a substantial section of the empirical part to this investigation, but turn before to a descriptive presentation on the magnitude of the 'va-et-vient' strategy in France.

\section{Description of the data}

\subsection{Data}

In this paper, we use a single cross-sectional data set in which the range of questions goes far beyond any traditional survey used until now for studying returning immigrants. The PRI (Passage à la Retraite des Immigrés) survey has been collected by the 'Caisse Nationale d'Assurance Vieillesse' from December 2002 to March 2003 in France, in collaboration with the 'Institut National de la Statistique et des Etudes Economiques'.

The sample of the PRI survey consists of 6211 individuals aged between 45 and 75, who were born abroad or of foreign nationality, but live in France at the date of the survey. Each respondent has been asked a wide range of questions related to his individual migration moves. Also, a detailed picture of the family members including parents, siblings and children is gathered together with the migration history, position with respect to either paid activity or retirement, health, intergenerational transfers, income, wealth and housing, and many other indicators of social assimilation, and total household income.

In order to better understand the location choices of migrants after retirement, one would ideally need a panel data set that follows individuals over the years and across the different locations. The cost of finding individuals after they move in another country is most probably prohibitive and therefore researchers often rely on migration intentions ${ }^{6}$. We proceed in the same way in this paper. Although this strategy is necessary considering the cross-sectional property of our data set, it is clear that it may be subject to potential bias due to subsequent changes of intentions. This potential bias has been extensively considered in Dustmann (2003), who showed that $86 \%$ of those who returned in the GSOEP between 1985 and 1997 had indicated their intention to return in 1984. Also, Gordon and Mohlo (1995) using the General Household

\footnotetext{
${ }^{5}$ Unobserved heterogeneity could be addressed by the use of a panel data and a regression in first difference that would remove time constant unobserved heterogeneity. In the same vein, measurement errors could be addressed by the use of a panel that follows intention of parents and location of children over a longer period of time.

${ }^{6}$ The GSOEP has been used for studying returns using the attrition property of the data set where a "moved abroad» is indicated (Dustmann, 2003, Constant and Zimmermann, 2003). Burda et alii (1998) have also used the GSOEP to investigate moving intentions of East Germans to West Germany.
} 
Survey found that $80 \%$ of individuals who expressed an intention to move had actually migrated within the following 5 years ${ }^{7}$.

In what follows, we focus on location intention of migrants when retiring. Indeed, descriptive evidence in France show that among migrants aged above 45 very few of them want to return to the origin country before retiring (see Attias-Donfut and Wolff, 2005). So, the location choice during old age appears to be made at the time of retirement, once individuals are no longer constrained by their job. In the questionnaire, the exact wording of the return intention question is: "at the time of your retirement, would you like to: stay in France - return to the origin country - perform the 'va-et-vient' between France and the origin country - do not know yet ?". When we restrict our analysis to respondents who are not retired at the time of the survey, the sample is reduced to 4336 observations. Since individuals are all over 45 year old, we can expect them to have a rather clear idea of their location decision when they retire.

\subsection{The magnitude of the va-et-vient decision}

In Table 1, we give the percentage for the different answers given to the preferred intended choice at retirement. Relatively few immigrants who live in France at the date of the survey claim that they will return to their home country (about 7\%), whereas a large proportion intends to stay in the host country $(58 \%)$. But the most striking figure is the very high proportion of those who state they will spend a fraction of the year in the host and in the home country. The frequency of the 'va-et-vient' strategy is around $24 \%$.

\section{Insert Table 1 bere}

As we are concerned with return intention when retiring, it matters to account for the number of years before retiring. Migrants who are expected to retire very soon have certainly a much more precise idea of their future location than migrants who still have to work for a decade or more. In Figure 1, we use age of respondent as a proxy for distance to retirement as we do not really know the age at retirement. In France, the bulk of workers retire at 60 , and a significant proportion is retiring between 55 and 60 . Self-employed people or shopkeepers tend to retire later. We observe that the older the immigrants, the more likely they intend to stay in France. This is of course linked to some selection effect, younger migrants being more likely to return to the origin country. Finally, the proportion of undecided individuals declines with age.

\section{Insert Figure 1 here}

A central issue is to know whether the importance of this 'va-et-vient' strategy is confined to our data, for instance owing to some strange features of the French pensions system that

\footnotetext{
7 See Manski (2003) for a demonstration of the importance of using intentions in economics.
} 
makes it particularly attractive. As described on websites linked to the French government, no restrictions are imposed on the payment made abroad for pensions accumulated in France ${ }^{8}$. This combined with the fact that $8 \%$ of pensions payment are made to residents abroad suggests that the 'va-et-vient' does not appear to be resulting from particularity of the French pensions system. The 'va-et-vient' has actually already been documented by other areas of specialisation. Sociologists observed a similar proportion of 'va-et-vient' for retired Italians and Spanish immigrants in Switzerland (Bolzman et al., 1993). Gerontologists have a related pattern amongst retirees, who spend part of the year in Southern sunnier states of US (Hogan and Steinnes, 1992, 1998, McHugh, 1990). Although the economic literature has until now neglected this case, it seems that the 'va-et-vient' decision does indeed constitute an extra strategy for retired migrants.

We have two other sources in the data set that confirms the importance of the 'va-etvient' choice at retirement. First, the intention of the partner (if any) is asked to the respondent (see Table 2). Not surprisingly, intentions are highly correlated, the corresponding proportions being equal to $21.1 \%$ for the 'va-et-vient' and $61 \%$ for the stay in the host country. Since both partners are expected to live in the same country during retirement, both decisions are highly interdependent. Also of interest is the fact that respondents are asked on the current choice of their friends and social network ("nationals", see Table 2). The choice of 'va-et-vient' appears even higher for those, as it is around 30\% among individuals from the same origin country as the respondent, whereas the choice to stay in France is slightly lower (around 40\%).

Insert Table 2 bere

\subsection{Description of parents and children}

For the purpose of our analysis, we focus on individuals who have reported a location decision (stay in France, return, or 'va-et-vient'), which leaves us with a sample of 3915 observations. Location intentions by origin countries are in Table 3. A comparison by continents shows that Europeans and Asian tend to favour mostly the stay in the host country, while Africans and Middle Easterners choose more often the 'va-et-vient'. But decomposing further the continents introduces large discrepancies. North Europeans tend largely to prefer to stay in France, and the same applies to Eastern Europeans. The 'va-et-vient' is a much more popular option amongst the Portuguese (41\%), whose intentions dominate by far all other single country considered. Many Tunisians currently living in France also intend to perform a 'va-et-vient'

\footnotetext{
8 A simple search on Google with the key words: "retraite à l'etranger" leads to official webpages indicating the apparent easy steps to claim pensions benefits in case of a move abroad (see for instance the following link http://www.expat.org/retraite/retraite_etranger.htm).
} 
between their origin country and France (40\%). Finally, the intention to return is comparatively more important for Central and Southern Africans, Portuguese and Americans.

Insert Table 3 here

In Table 4, we present the characteristics of the sample according to the three intended choice given by the respondents. Females on average tend to desire more often to stay in the host country, the same applies for older individuals. The 'va-et-vient' appears to be more popular amongst men and younger individuals. More years of education does increases the decision to stay in France. Intentions to stay in the host country are more likely with many years since migration, whereas the more recent immigrants favour a return. The 'va-et-vient' appears to be the preferred choice for immigrants with intermediate years since migration (from 20 to 39 years). Finally, levels of income (measured at the household level) do not seem to be associated with any clear-cut location intention?.

\section{Insert Table 4 bere}

Let us now turn to the locations of the other family members. Information is not the same for all family members. We know the country of residence of parents and siblings of respondents at the time of interview. For other family members (grandparents, uncles, aunts, etc), respondents communicate whether some of them are living in the origin country, without further details on their position within the extended family. Characteristics of children of interviewees are well described. For each of them, the survey provides their age, their country of birth, and their current country of living. No information is provided on the intended location of family members at the time of retirement for interviewees.

More than 8 over 10 respondents with parents in France intend to stay at retirement. Conversely, only $58 \%$ of respondents who have parents living in the origin country intend to stay in France. Only few immigrants have got no children in France (10.5\%), and a similar proportion has children in the home country $(13.5 \%)$. When the respondent has children in France, the preferred location choice at retirement is the host country for $66.1 \%$ of migrants, but this proportion equals only $52.7 \%$ when there are some children in the origin country. In the latter case, we observe a significant increase in the probability of returning in the origin country, respectively $17.1 \%$ instead of $7.2 \%$, and the frequency of 'va-et-vient' is also slightly higher.

As children may have a particular role in our analysis, owing to filial attention with parents, we now further describe the children population. By definition, we have to focus only on respondents who have at least one child. Also, parents may have several children and we have

\footnotetext{
${ }^{9}$ In the PRI survey, there is no information concerning the migrant's level of personal income. This is certainly not problematic in the context of our problem, since the migration decision at retirement is likely to be a joint decision from both spouses, as shown by the descriptive statistics reported in Table 1.
} 
information for each of them. Hence, we construct a new sample where each child is now counted as an observation. We end up with a new sample of 11349 parent-child pairs (called the child sample), which includes 3659 parents. In Table 4, we report descriptive statistics for gender, age, living with parents, actual location (origin country or France) and born place.

We first note that around $65 \%$ of children are aged 20 or more. We find that parents of older children are more likely to intend to stay in France, which is most probably due to the positive association between age of parents and age of children. At the time of interview, already $45 \%$ of children do not live with their parents anymore. This proportion is expected to increase as parent grow older and approach retirement. According to the PRI survey, about $27 \%$ of all children were born in the origin country. Also, the vast majority of children are living in the host country at the time of interview (91\%). For children who live in the origin country (less than 9\%), parents are more likely to favour a return (nearly $20 \%$ ) or a 'va-et-vient' (32\%).

So, our descriptive results suggest that family location matters when explaining migrants' location at retirement. As individual characteristics differ widely depending on whether respondents intend to stay in France, to return to the origin country or to perform a 'va-et-vient' across both countries, we now turn to a multivariate analysis.

\section{Econometric analysis}

\subsection{Empirical strategy}

According to the data, each migrant faces three location decisions. He may either stay in the host country $(j=1)$, return to the origin country $(j=2)$ or spend some time in both the origin and host countries $(j=3)$. For these random alternatives, we denote the corresponding utilities by $U_{j}=\beta_{j} X+\varepsilon_{j}$, with $X$ a set of individual explanatory variables, $\beta_{j}$ the associate vector of coefficients for each alternative $j(j=1,2,3)$, and $\varepsilon_{j}$ a random perturbation. The probability for a migrant to choose outcome $j$ is $\operatorname{Pr}(j)=\operatorname{Pr}\left(U_{j}>U_{k}, U_{j}>U_{l}\right)$, with $k, l \neq j$.

Under the assumption that the stochastic utilities are independently and identically distributed with extreme value distribution, the corresponding model is the classic multinomial Logit model. The probability of occurrence for the alternative $j$ is $\operatorname{Pr}(j \mid X ; \beta)=e^{\beta_{j} X} / \sum_{i=1}^{3} e^{\beta_{i} X}$. Since choice depends only on utility differences, identification is achieved by normalizing the utility of an alternative to zero. We will always define the intention to stay in France as the base category. Estimation of the MNL model is straightforward, but a central problem is its underlying assumption of independence of irrelevant alternatives, such that the odds for any pair of outcomes are determined without reference to the other outcomes that might be available. 
In our analysis, we test the IIA assumption using a Hausman-type test proposed by Hausman and McFadden (1984). The test involves three subsequent steps. First, we estimate the full model with all outcomes included, the resulting vector of estimated coefficients is $\hat{\beta}_{F}$. Second, we estimate a restricted model by eliminating one outcome category and obtain the estimates $\hat{\beta}_{R}$. If $\hat{\beta}_{F F}$ is the subset of $\hat{\beta}_{F}$ after eliminating coefficients not estimated in the restricted model, the Hausman test of IIA is $H_{I I A}=\left(\hat{\beta}_{R}-\hat{\beta}_{F F}\right)^{\prime}\left[\hat{V}\left(\hat{\beta}_{R}\right)-\hat{V}\left(\hat{\beta}_{F F}\right)\right]^{-1}\left(\hat{\beta}_{R}-\hat{\beta}_{F F}\right)$. The statistic $H_{I I A}$ is asymptotically distributed as chi square, degrees of freedom being equal to the number of raws in $\hat{\beta}_{R}$ under the null hypothesis (i.e if IIA holds true). As $\hat{V}\left(\hat{\beta}_{R}\right)-\hat{V}\left(\hat{\beta}_{F F}\right)$ is not necessarily positive semi-definite, $H_{I I A}$ can be negative ${ }^{10}$.

\subsection{Results assuming exogenous location of family members}

For the estimation, we begin by estimating the MNL model where we only introduce the characteristics of the migrants, including their origin country. We include as covariates in the regression gender, age, presence of a spouse, age at migration, years of education and a measure of the household's income. We subsequently discuss the effect of the additional family variables dealing with the location of parents, children, siblings and more distant relatives. We report the corresponding estimates in Table 5, the base category being the decision to stay in France. To make the interpretation of estimates easier, we present the relative risk ratios and their standard errors.

We first consider the decision to return to the origin country, staying in France being the reference. This choice is less likely for women, while living in couple is not relevant for the optimal choice. Years of education exert a negative impact, each additional year leading to a decrease of $2.2 \%$ in the return probability. Income measured at the household level does not influence the return decision. The location choice is strongly influenced by the migrant's trajectory, since duration of migration significantly reduces the return decision. Staying in France one additional year reduces by $3.5 \%$ the probability to return to the origin country. As the migrant's age is also the sum of age at entry and duration of migration, this means that a migrant who is arrived in France early in his life cycle has a strong preference for staying in France at retirement. All those findings are not surprising ${ }^{11}$.

\footnotetext{
${ }^{10}$ On this point, see the further discussion in Hausman and McFadden (1984). In our context, several Hausman tests of the IIA are possible. After having chosen a base category, two tests can be conducted by excluding each of the remaining categories to form the restricted model. Another test can be computed by changing the base category.

${ }^{11}$ To further investigate this result that better assimilated migrants are less likely to return, we have also estimated models with dummy variables for respondents holding the French citizenship and owning a home in the home
} 


\section{Insert Table 5 bere}

In order to control for country heterogeneity, we also introduce in the regression a set of dummy variables corresponding to the different regions of origin. With respect to countries of Northern Europe, the probability to return is significantly increased for persons originating from countries of Southern Europe and Central and South of Africa. The probability to return is also slightly higher for migrants from Asia (at the 10 percent level).

Turning to the 'va-et-vient' strategy, we first observe that several characteristics have a similar impact on the 'va-et-vient' and the return decision. The probability of 'va-et-vient' is less important for women, high-educated persons, and both age and migration duration exert a negative impact on this location choice. As opposed to the return category, we now observe that household's income has a positive effect on the 'va-et-vient' decision (at the 5\% level). A simple explanation is that increased housing and travel costs are associated to the 'va-et-vient' strategy, so that poorer or liquidity constrained households are less likely to share their time between two different countries.

As for the country effects, we observe that the 'va-et-vient' intention is much more frequent for migrants coming from Southern Europe, and to a lesser extent from Northern Africa and Middle East. That the 'va-et-vient' is more common for migrants coming mainly from Italy, Spain or Portugal may be due to by the geographical proximity to France. However, a similar argument in terms of distance should be also relevant to the Northern countries, but this is absolutely not the case as the 'va-et-vient' is less often quoted by migrants originating from these countries. Better climate seems then to be important when one focus on the pattern of the migrants location at the time of retirement (a result already observed for British retired natives, King et al., 2000).

Two additional comments are in order concerning these MNL estimates. First, when testing the relevance of the IIA assumption, we obtain a negative test statistics (see Table 5). As pointed out in Hausman and McFadden (1984, p. 1226), it is evidence that the IIA assumption has not been violated. Second, when comparing estimates respectively for the return and for the 'va-et-vient' decisions, we have shown that many characteristics were acting in the same direction. So, it seems worthwhile to know whether the 'va-et-vient' choice is really a different one from the return strategy. We perform a simple Wald test for linear hypothesis and investigate whether the coefficients of the covariates are identical for both the return and 'va-et-vient' decisions. The null

country. Although both covariates are most probably endogenous to the location decision, they are negatively and significantly associated with the return probability at retirement. 
assumption is clearly rejected, and we take this as further evidence that the 'va-et-vient' strategy is a different choice deserving more investigation ${ }^{12}$.

We then reestimate the MNL model introducing additional variables describing the location of other family members (see Table 5). In general, the effects of covariates remain unaltered, although there are some slight differences. The coefficient for years since migration is still significant, but its magnitude is now much lower. This is an interesting result as this coefficient approximates better the 'true' assimilation in the host country as family variables are now controlled for. As suggested in our theoretical discussion, family variables are highly relevant to explain both return and 'va-et-vient' intentions.

We note that the different variables dealing with family locations are all significant for the return decision, except for the presence of parents in France. Returns are strongly associated with the location of siblings, other family in the origin country and children. It is a decreasing function of those family members who are currently living in France and is more likely when the migrant has parents, siblings, other family members and children in the origin country.

Results are slightly different for the 'va-et-vient' decision, though the data clearly indicates that these family location variables are also jointly significant. Having parents in France strongly reduces this location choice at retirement, while the impact of siblings in France is less significant than compared to the return decision and having children living in France does not influence the immigrants intent. Siblings, other family members and especially children in the origin country strongly increases the probability for the migrant to choose the 'va-et-vient', while parents located in the home country is insignificant.

Generally, those results confirm the idea put forward by Dustmann (2003) of explaining return migration by family variables. Nevertheless, this author was not able to distinguish the children according to their current location in the home or the origin country. The use of our more comprehensive data allows us to empirically demonstrate that the present location of not only children, but also other family members is necessary to understand location's decision of retirees. Now, the question arises of whether we can give a causal interpretation to those family variables on the optimal location of the respondents at retirement.

\subsection{Family location as an endogenous process}

Until now, we have assumed that respondents take their retirement decisions conditional on the location of other family members. As previously discussed, this interpretation may be problematic owing to the endogeneity of location choices. In particular, it is likely that decisions within the household are taken simultaneously. Other family members may also choose to move

\footnotetext{
12 The corresponding statistic is equal to 61.8 with 13 degrees of freedom, and thus highly significant.
} 
where parents would like to spend time when retiring. For instance, children may have a higher propensity to return home if parents express a wish that they would like to retire in their home country. Let us further investigate this problem.

We should first emphasise that the severity of the endogeneity problem most probably differs across the family ties considered in the analysis. In particular, consider first the ties between respondents and their siblings. Keeping in mind that our sample is composed of older individuals (of at least 45), siblings can be expected to have their own children, parents-in-law and other friends and ties. It appears rather improbable that siblings may choose a location choice depending on the expected location of respondents at retirement. Also assuming that siblings do not retire at the same time, the costs of multiple moves caused by the location of siblings appears to be much too high. Similar reasoning applies to other family members such as aunts and uncles. Parents of respondents are rather old when the respondents retire, so that they certainly will not react to the children's location decision when aged of 80 or more ${ }^{13}$.

We believe that this is mostly in the case of the respondent-children relationship that the question of endogeneity arises. On the one hand, young children may be forced to join their parents who decided to return (in a tied move). On the other hand, children may decide to move where their parents intend to spend their retirement for caregiving purposes. If that is the case, then the estimated coefficients previously presented cannot be interpreted as causal. Here, we would like to point out that this problem is much more relevant for the return than for the 'va-etvient'. This latter choice is, in most cases, not feasible for active children. Very few jobs offer sufficient flexibility to allow the worker to split the residence across two different countries during the year.

One way of testing for the presence of simultaneity in the location decisions is to investigate the association between the location decision of respondents and the effect of their daughters and sons. Interestingly, although fertility decisions may be taken simultaneously with return decisions, the gender of the child is always exogenous (see the discussion in Dustmann, 2003). In a regression of the intended location at retirement of individuals on their children differentiated by sex, an endogenous location decision would imply the coefficients for girls and boys to be identical. Evidence of different coefficients is compatible with a story where children cause parental location decision. Assuming further that parents consider the origin country environment as more beneficial for daughters than for sons, we can expect the coefficients for girls to be positive, implying more returns for parents. Another justification for the positive association can be that older parents of adult daughters choose to locate closer to their daughters 13 The resulting costs (financial and health related) of a move for them are again certainly much too high at this later
stage of life to be recovered by subsequent benefits. 
for caregiving purposes (adult daughters tend to provide more care to their parents than adult sons, ..)

Our results are in Table 6. A first comment of interest is that children coefficients are generally not significant for the return in the home country in models where we do not introduce the location of children (models 1 to 3). Conversely, they are significant when introducing child location (model 4). For the 'va-et-vient', the opposite result is observed. This result suggests that individuals tend to reduce the cost of separation from the family by adopting such a strategy. Spending part of the year in each country allows respondents to maintain contacts with children wherever they live (in the host or the origin country).

\section{Insert Table 6 bere}

Young children tend be associated negatively with the propensity to realise the 'va-etvient' (model 1) ${ }^{14}$. Adding in model 2 the number of daughters implies that the coefficient for children measures now the effect of sons only. We observe significantly different estimates for sons and daughters. Each boy under 16 decreases the probability to conduct a 'va-et-vient', whereas each girl under 16 increases this probability. This is incompatible with a simultaneous decision on fertility and location decision at retirement, and suggests that the coefficients can be taken as causing the decision to conduct a 'va-et-vient'. When looking at the effect of children whatever their age, the corresponding estimates are no longer significant. Similarly when the locations of children (in the host or the origin country) are introduced, the estimates are no longer significant.

For the return versus the stay in the host country, we find few effects of children when their location is not differentiated. When we introduce those living in the host and the home country, we find that each additional boy living in France decreases the probability of return, while this probability is strongly increasing with the number of boys living in the origin country (model 4, Table 6$)^{15}$. Also and more importantly, the differences between the coefficients of sons and daughters are significant, at the 6 percent level for children living in France, and at the 2 percent level for children located in the origin country. We interpret those results as further support for a story where children cause the location of parents.

All those results are observed given the present location of children. In order to further investigate the potential endogeneity of the child location in the intended location of parents, we finally turn to a simultaneous model where the determinants of the current location of the children are estimated jointly with the intended location of the respondents at retirement. For

\footnotetext{
${ }^{14}$ We obtain similar results when we control for the other family variables introduced in Table 5 . We chose to exclude them as there may be potentially endogenous in the location decision of parents.

${ }^{15}$ We note that the coefficients for daughters are not significant, a similar result than Dustmann, (2003).
} 
that purpose, we use the 'child sample' where each child is counted as an observation (11349 children). Results are reported in Table 7.

\section{Insert Table 7 here}

We first estimate a multinomial Logit model to explain the parent's choice of preferred location at retirement and introduce a dummy variable when the child lives in the origin country. So, the child's location is assumed exogenous in the regression (model 1, Table 7). We correct the standard-errors for potential correlation of the parental choice across children in the same family using the Hubert-White method (White, 1980) ${ }^{16}$. We find similar results to those described in Table 5. That the child lives in the origin country is associated with an increase propensity to return and to realise a 'va-et-vient'. Then, we relax the exogeneity assumption and estimate the same model with an instrumented child's location.

Let us briefly describe the econometric specification. First, there is an equation for the parent's preferred location at retirement $j$ given by $U_{j}=\beta_{j} X_{j}+\delta_{j} L_{k}+\varepsilon_{j}$, where $k$ as subscript stands for the child, $L_{k}$ is the current location of the child (it is equal to 1 when the child is located in the origin country, and to 0 otherwise), and $\varepsilon_{j}$ is a random perturbation. The residuals $\varepsilon_{j}$ are extreme value distributed. Second, there is an equation for the child's location, which is given by $L_{k}^{*}=\alpha Z_{k}+\mu_{k}, L_{k}^{*}$ being the latent value associated to $L_{k}$. Clearly, $L_{k}$ is equal to one when the child lives in the origin country, and to 0 otherwise. Finally, $\mu_{k}$ is a random perturbation normally distributed. The parameter of interest for our analysis is $\delta_{j}$.

Both equations define a simultaneous recursive model with one Probit equation for the child's location and a MNL Logit for the parent's preferred location with the child's location as an additional explanatory variable. For the estimation, we turn to the following two step methodology. In a first step, we estimate the Probit equation by maximum likelihood. In a second step, we estimate the multinomial Logit model and add the predicted probability of the child's location computed from the model in the first step. Importantly, covariance matrices for two step matrices have to be adjusted. Specifically, we draw on the general method described in Murphy and Topel (1985) to get corrected standard errors (model 2, Table 7$)^{17}$.

\footnotetext{
${ }^{16}$ It is not possible to control for unobserved heterogeneity by introducing fixed effects in the regression since the choice of a parent is identical across all children of the same family.

${ }^{17}$ We have also estimated the recursive model using a maximum likelihood method. For that purpose, we add to the MNL model an unobserved heterogeneity term (specific to each observation) and suppose that this perturbation and the residual of the Probit equation follow a bivariate normal distribution with unitary variances and a correlation coefficient taking a value in the range -1 to 1 . We estimate jointly the Probit and the multimomial Logit equations by maximising the corresponding likelihood function. Residuals are integrated out numerically, since no closed form solution to the likelihood exists (see the discussion in Lillard and Panis, 2003). We observe that results reported for the model 3 in Table 7 are very close to those obtained with the two-step approach, where the predicted probability
} 
When estimating the joint model, the location of each child is explained by gender, age and birthplace of the child. We expect the birthplace to have a significant influence on the future location of the child. Children born in France hold the French nationality, whereas those born abroad will face much more difficulties to obtain it. Girls are also expected to be located preferably in the origin country if the cultural environment is judged more beneficial for them. Younger children are also more likely to be located in the same country as their parents at the time of interview, as they are not financially independent. Conversely, older child may make their own decision to move back to the country of origin.

The joint results in model 2 of Table 7 indicate first that the probability for a child to live in the origin country is greater for female and older children, and it also much higher when the child is born in the origin country. Also, we find that the coefficient for the child location in the origin country is still significant for the return versus the stay in the host country. Conversely, it is negative, but not significant for the 'va-et-vient' versus the stay in the host country. This is further support for a story where the child's location is less relevant for the 'va-et-vient', as parents may spend part of the year in each country and then minimise the cost of separation. And generally, those estimates confirm that for the return, the location of children appear to cause parents location at retirement.

\section{Concluding comments}

In this paper, we investigate a new migration strategy for immigrants at the time of their retirement, which is to spend a fraction of the year in the host and the rest in the origin country. We explain why this strategy is unlikely to be confined to our data set and argue that it may be chosen by the increasing proportion of workers who reach retirement while having migrated earlier during their working life. We show that the main determinants of this «va-et-vient » for French migrants differ significantly with respect to the choice of making a definite return to the origin country. Most notably, immigrants from Southern Europe, Northern Africa and the Middle East are more likely to choose this strategy. This is also the case for richer households, lower educated individuals and those who migrated more recently in the host country.

When investigating the effect of family ties, we discuss their potential endogenous location with respect to the choice of respondents. We argue that this endogeneity is more likely to arise for children, and is less likely to bias our estimates for more distant relatives. When investigating the effect of children, we use an identifying strategy related to Dustmann (2003) that relies on the randomness of the sex composition of siblings. We find support for a story where

for the child to live in the origin country is introduced into the MNL Logit equation for the parental preferred location. Results are available on request. 
children cause location choice of respondents at retirement. An interpretation for this outcome is that respondents reduce the cost of separation from their children and family ties by choosing to perform a «va-et-vient » between the host and the origin country at retirement.

This is a new result with respect to the previous migration literature, which has important policy applications with respect to housing markets, economic growth, remittances, or social assimilation. Along with additional evidence on the magnitude of this phenomenon, a better understanding of the consequences of the 'va-et-vient' strategy by migrants is needed, and we leave these issues for future research. 


\section{References}

Bolzman, C., Fibbi, R. and Vial, M. (1993), "Les Immigrés Face à la Retraite: Rester ou Retourner?" Swiss Journal of Economics and Statistics, 129(3), 371-384.

Burda, M., Haerdle, W., Mueller, M. and Werwatz, A., (1998), "Semiparametric Analysis of German EastWest Migration Intentions: Facts and Theory", Journal of Applied Econometrics, 13, 525-541.

Bergstrom T., (1996), 'Economics in a family way', Journal of Economic Literature, vol. 34, pp. 1903-1934.

Constant, A. and Zimmermann, K., (2003), "The Dynamics of Repeat Migration: A Markov Chain Analysis", CEPR Discussion Paper no. 4124, London, Centre for Economic Policy Research.

CNAV, (2002), Caisse Nationale d'Assurance Vieillesse, Statistiques de la Branches Retraite, Etudes et Documentations, Retraités du régime, http://www.cnav.fr/5etude/frameset.htm

Dustmann C., (2001), Why go back? Return Motives of Migrant Workers, Chapter 11 in International Migration: Trends, Policy, and Economic Impacts, S. Djajic (ed), Routledge, N.-Y.

Dustmann, C., (2003), Children and Return Migration, Journal of Population Economics, vol. 16, pp. 815-30

Djajic, S. and Milbourne, R., (1988), 'A general equilibrium model of guest worker migration', International Economic Review, vol. 25, pp. 335-351.

Ehrlich I., Lui F.T., (1991), 'Intergenerational trade, longevity and economic growth', Journal of Political Economy, vol. 99, pp. 1029-1059.

Gordon, I. and Mohlo. I, (1995), Duration Dependence in Migration Behaviour: Cumulative Inertia versus Stochastic Change, Environment and Planning A, 27, 1961-1975.

Gustavson, P., (2001), Retirement Migration and Transnational Lifestyle, Ageing and Society, 21, pp. 371394.

Hausman, J.A.. and MacFadden, D., (1984), Specification Tests for the Multinomial Logit Model, Econometrica, 52(5), pp. 1219-1240.

Hogan, T., and Steinnes, D., (1992), Take the Money and Sun, Journal of Gerontology, 47(4), S197-203.

Hogan, T., and Steinnes, D., (1998), A logistic Model of the Seasonal Migration Decision for Elderly Households In Arizona and Minnesota, Gerontologist, 38(2), pp. 152-158.

ILO, (2003), Policy Response to Skilled Migration: Retention, Return and Circulation, Perspectives on Labour Migration, 4.

Konrad K.A., Künemund H., Lommerud K.E., Robledo J.R., (2002), 'Geography of the family', American Economic Review, vol. 92, pp. 981-998.

Jellal M., Wolff F.C., (2002), 'Cultural evolutionary altruism : Theory and evidence', European Journal of Political Economy, 18(2), pp. 241-262.

King, R., Warnes, A.M. and Williams, A.M., (1998) International retirement migration in Europe, International Journal of Population Geography, 4(2), pp. 91-111.

King, R., Warnes, A.M. and Williams, A.M., (2000), Sunset Lives: British Retirement Migration to the Mediterranean. Oxford: Berg

Laferrère A., Wolff F.C., (2004), 'Microeconomic models of family transfers', in S.C. Kolm, J. Mercier Ythier (eds), Handbook on the Economics of Giving, Reciprocity and Altruism, North-Holland, Elsevier.

Lillard L.A., Panis C.W.A., (2003), aML Multilevel Multiprocess Statistical Software, EconWare, Los Angeles, California.

Manski, C., (2003), "Inferences on Expectations and Decisions", Fischer Schultz Lecture at the European Economic Association \& Econometric Society, Stockholm, http://www.eea-esem.com/eeaesem/2003/prog/viewpaper.asp?pid=2975 
MacHugh, K., (1990), Seasonal migration as a substitute for, or precursor to, permanent Migration, Research on Ageing, 12(2), pp. 229-245.

Murphy K.M., Topel R.H., (1985), "Estimation and inference in two-step econometric models", Journal of Business and Economic Statistics, vol. 3, pp. 370-79

Sloan F.A., Zhang H.H., Wang J., (2002), 'Upstream intergenerational transfers', Southern Economic Journal, vol. 69, pp. 363-380

White H., (1980), 'A heteroskedasticity-consistent covariance matrix estimator and a direct test for heteroskedasticity', Eonometrica, vol. 48, pp. 817-838. 
Table 1. Preferred intended location at retirement for the respondent (in \%)

\begin{tabular}{|l|c|c|c|c|c|}
\hline Location choice of respondents & Less than 50 & $51-55$ & $56-60$ & $\begin{array}{c}\text { More than } \\
60\end{array}$ & All \\
(N=4336) & & & & 70.3 & 59.1 \\
\hline France & 55.1 & 57.6 & 63.4 & 6.4 & 7.2 \\
Return to origin country & 7.2 & 8,3 & 5.8 & 17.5 & 24.0 \\
'Va-et-vient' & 25.7 & 24.7 & 22.7 & 8.8 & 9.7 \\
Do not know yet & 12.1 & 9.3 & 8.1 & 5.8 \\
\hline
\end{tabular}

Survey PRI 2003. 
Table 2. Preferred location at retirement for partner and fellow countrymen (\%)

\begin{tabular}{|c|c|}
\hline Partner $^{(1)}(\mathrm{N}=3647)$ & 61.3 \\
France & 8.5 \\
Return to origin country & 21.1 \\
'Va-et-vient' & 9.1 \\
Do not know yet & \\
\hline Fellow countrymen (2) (N=4336) & 39.4 \\
France & 10.5 \\
Return to origin country & 29.2 \\
'Va-et-vient' & 12.7 \\
Do not know anybody with same nationality & 4.0 \\
Differs with generation & 1.2 \\
Differs between ethnic groups & 3.0 \\
Do not know & \\
\hline
\end{tabular}

Survey PRI 2003.

(1) Only asked to respondents with a partner

(2) Respondents are asked about regular choices for individuals from the same origin country as the respondent. 
Table 3. Preferred location by origin country

\begin{tabular}{|c|c|c|c|}
\hline \multirow[t]{2}{*}{ Origin country } & \multicolumn{3}{|c|}{ Preferred location } \\
\hline & France & Origin country & 'Va-et-vient' \\
\hline Europe & 67.2 & 7.9 & 24.9 \\
\hline Northern Europe & 84.9 & 3.7 & 11.4 \\
\hline Southern Europe & 62.9 & 9.1 & 28.0 \\
\hline Italy & 86.9 & 4.5 & 8.6 \\
\hline Portugal & 46.8 & 12.0 & 41.2 \\
\hline Spain & 73.5 & 7.9 & 18.6 \\
\hline Eastern Europe & 77.5 & 3.1 & 19.4 \\
\hline Africa & 62.9 & 7.8 & 29.3 \\
\hline Northern Africa & 66.1 & 4.8 & 29.1 \\
\hline Morocco & 67.9 & 5.8 & 26.4 \\
\hline Algeria & 70.0 & 3.0 & 27.0 \\
\hline Tunisia & 53.7 & 6.6 & 39.7 \\
\hline Central and Southern Africa & 49.3 & 20.7 & 30.0 \\
\hline America & 60.9 & 12.0 & 27.2 \\
\hline Middle-East & 62.2 & 6.7 & 31.1 \\
\hline Asia & 72.4 & 8.6 & 19.0 \\
\hline Total $(\%)$ & 65.5 & 7.9 & 26.6 \\
\hline
\end{tabular}

Survey PRI 2003. 
Table 4. Descriptive statistics

\begin{tabular}{|c|c|c|c|c|c|}
\hline \multirow{2}{*}{\multicolumn{2}{|c|}{ Individual characteristics }} & \multicolumn{3}{|c|}{ Preferred location when retiring for respondents } & \multirow{2}{*}{$\begin{array}{c}\text { Column } \\
\text { percentages }\end{array}$} \\
\hline & & France & Origin country & 'va-et-vient' & \\
\hline \multicolumn{6}{|l|}{ RESPONDENT [ $\mathrm{N}=3915$ ] } \\
\hline \multirow{2}{*}{ Sex } & Male & 62.0 & 8.4 & 29.6 & 57.0 \\
\hline & Female & 70.1 & 7.2 & 22.7 & 43.0 \\
\hline \multirow{3}{*}{ Age } & Less than 50 & 62.9 & 8.5 & 28.6 & 29.7 \\
\hline & $50-54$ & 62.9 & 9.0 & 28.1 & 31.3 \\
\hline & 55 plus & 69.6 & 6.6 & 23.8 & 39.0 \\
\hline Mean age & & 53.3 & 52.6 & 52.6 & 53.1 \\
\hline \multirow[t]{2}{*}{ Has a partner } & No & 69.8 & 8.3 & 21.9 & 15.0 \\
\hline & Yes & 64.7 & 7.9 & 27.4 & 85.0 \\
\hline \multirow[t]{3}{*}{ Years of schooling } & 5 less & 59.2 & 9.0 & 31.9 & 45.3 \\
\hline & $6-11$ & 72.4 & 7.0 & 20.7 & 29.4 \\
\hline & 12 plus & 68.8 & 7.2 & 24.0 & 25.3 \\
\hline \multirow[t]{4}{*}{ Years since migration } & $0-19$ & 64.6 & 13.7 & 21.7 & 11.5 \\
\hline & $20-29$ & 59.5 & 8.6 & 31.9 & 23.4 \\
\hline & $30-39$ & 61.0 & 8.4 & 30.6 & 38.3 \\
\hline & 40 plus & 87.0 & 2.4 & 10.6 & 18.3 \\
\hline \multirow{4}{*}{ Household income } & Quartile 1 & 68.1 & 8.6 & 23.4 & 25.0 \\
\hline & Quartile 2 & 66.1 & 8.0 & 25.9 & 25.0 \\
\hline & Quartile 3 & 60.3 & 9.0 & 30.7 & 25.0 \\
\hline & Quartile 4 & 67.5 & 6.2 & 26.4 & 25.0 \\
\hline \multirow[t]{2}{*}{ Parents in France } & No & 62.1 & 8.6 & 29.3 & 83.6 \\
\hline & Yes & 82.9 & 4.3 & 12.7 & 16.4 \\
\hline \multirow[t]{2}{*}{ Parents in origin country } & No & 70.2 & 6.6 & 23.2 & 61.4 \\
\hline & Yes & 58.0 & 10.0 & 32.0 & 38.6 \\
\hline \multirow[t]{2}{*}{ Siblings in France } & No & 62.5 & 9.2 & 28.2 & 51.5 \\
\hline & Yes & 68.6 & 6.5 & 24.9 & 48.5 \\
\hline \multirow[t]{2}{*}{ Siblings in origin country } & No & 76.5 & 5.0 & 18.5 & 31.9 \\
\hline & Yes & 60.3 & 9.3 & 30.4 & 68.1 \\
\hline \multirow[t]{2}{*}{ Children in France } & No & 60.3 & 13.9 & 25.8 & 10.5 \\
\hline & Yes & 66.1 & 7.2 & 26.7 & 89.5 \\
\hline \multirow[t]{2}{*}{ Children in origin country } & No & 67.5 & 6.5 & 26.0 & 86.5 \\
\hline & Yes & 52.7 & 17.2 & 30.1 & 13.5 \\
\hline \multicolumn{6}{|c|}{ CHILDREN [N = 11349] } \\
\hline \multirow[t]{2}{*}{ Sex } & Male & 65.0 & 8.0 & 27.0 & 51.6 \\
\hline & Female & 63.1 & 8.0 & 28.9 & 48.6 \\
\hline \multirow[t]{4}{*}{ Age } & Less than 10 & 62.1 & 9.3 & 28.6 & 7.2 \\
\hline & From 10 to 19 & 60.9 & 9.1 & 30.0 & 28.2 \\
\hline & From 20 to 29 & 62.7 & 7.9 & 29.4 & 43.2 \\
\hline & 30 and more & 71.9 & 6.2 & 21.9 & 21.5 \\
\hline \multicolumn{2}{|l|}{ Mean age } & 23.0 & 21.5 & 21.6 & 22.5 \\
\hline \multirow[t]{2}{*}{ Live with parents } & No & 67.0 & 8.2 & 24.8 & 44.7 \\
\hline & Yes & 61.8 & 7.8 & 30.5 & 55.3 \\
\hline \multirow[t]{2}{*}{ Born in the origin country } & No & 65.4 & 6.7 & 28.0 & 72.6 \\
\hline & Yes & 60.8 & 11.4 & 27.8 & 27.4 \\
\hline Living in the origin country 1 & No & 65.6 & 6.9 & 27.5 & 91.3 \\
\hline & Yes & 48.2 & 19.5 & 32.4 & 8.7 \\
\hline
\end{tabular}

Survey PRI 2003.

Note: Statistics on respondents are calculated with the respondent sample (3915 observations). Statistics on children are calculated with the child sample, where each child of the respondent is counted as one observation (11349 observations). 
Table 5. MNL models of the location decision

\begin{tabular}{|c|c|c|c|c|c|c|c|c|}
\hline Variables & $\operatorname{Re}$ & & Va-e & ient & & & Va-e & ient \\
\hline & $\begin{array}{l}\text { Odd } \\
\text { ratio }\end{array}$ & s.e. & $\begin{array}{l}\text { Odd } \\
\text { ratio }\end{array}$ & s.e. & $\begin{array}{l}\text { Odd } \\
\text { ratio }\end{array}$ & s.e. & $\begin{array}{l}\text { Odd } \\
\text { ratio }\end{array}$ & s.e. \\
\hline Respondent's characteristics & & & & & & & & \\
\hline Female & $0.660^{* * *}$ & 0.088 & $0.680^{* * *}$ & 0.056 & $0.674^{* * *}$ & 0.092 & $0.685^{* * *}$ & 0.057 \\
\hline Age $\left(10^{\mathrm{e}}-2\right)$ & 0.858 & 1.067 & $0.219^{*}$ & 0.171 & $0.024^{* * *}$ & 0.034 & $0.012^{* * *}$ & 0.011 \\
\hline Years since migration $\left(10^{\mathrm{e}}-2\right)$ & $0.001^{* * *}$ & 0.001 & $0.012^{* * *}$ & 0.006 & $0.014^{* * *}$ & 0.012 & $0.102^{* * *}$ & 0.055 \\
\hline Live in couple & 0.936 & 0.168 & 1.122 & 0.130 & 1.019 & 0.191 & 1.102 & 0.133 \\
\hline Years of education $\left(10^{\mathrm{e}}-2\right)$ & $0.011^{* * *}$ & 0.015 & $0.028^{* * *}$ & 0.024 & $0.029^{* *}$ & 0.041 & $0.073^{* * *}$ & 0.064 \\
\hline Household's income (10e-5) & 0.916 & 0.282 & $1.364^{* *}$ & 0.187 & 0.903 & 0.284 & $1.364^{* *}$ & 0.190 \\
\hline Origin country (reference $=$ Northern Europe) & & & & & & & & \\
\hline Southern Europe & $5.570^{* * *}$ & 2.064 & $4.335^{* * *}$ & 0.963 & $7.220^{* * *}$ & 2.734 & $4.751^{* * *}$ & 1.069 \\
\hline East Europe & 1.068 & 0.607 & $2.044^{* *}$ & 0.583 & 1.255 & 0.721 & $2.146^{* * *}$ & 0.615 \\
\hline North Africa & 1.731 & 0.660 & $3.120^{* * *}$ & 0.692 & $2.062^{*}$ & 0.809 & $3.161^{* * *}$ & 0.714 \\
\hline Middle and South of Africa & $8.161^{* * *}$ & 3.065 & $3.809^{* * *}$ & 0.936 & $9.599^{* * *}$ & 3.741 & $3.823^{* * *}$ & 0.958 \\
\hline America & $4.389^{* * *}$ & 2.070 & $3.172^{* * *}$ & 1.000 & $5.174^{* * *}$ & 2.484 & $3.270^{* * *}$ & 1.039 \\
\hline Middle East & 2.002 & 0.923 & $2.971^{* * *}$ & 0.782 & $2.444^{*}$ & 1.151 & $3.035^{* * *}$ & 0.813 \\
\hline Asia & $2.208^{*}$ & 0.920 & $1.599^{*}$ & 0.425 & $3.579^{* * *}$ & 1.534 & $2.041^{* * *}$ & 0.554 \\
\hline Family location & & & & & & & & \\
\hline Parents in France & & & & & 0.769 & 0.199 & $0.415^{* * *}$ & 0.064 \\
\hline Parents in home country & & & & & $1.288^{*}$ & 0.186 & 1.087 & 0.095 \\
\hline Siblings in France & & & & & $0.709^{* *}$ & 0.097 & $0.850^{* *}$ & 0.070 \\
\hline Siblings in home country & & & & & $1.526^{* *}$ & 0.260 & $1.317^{* * *}$ & 0.132 \\
\hline Other family members in home country & & & & & $1.625^{* *}$ & 0.373 & $1.470^{* * *}$ & 0.186 \\
\hline Children in France & & & & & $0.598^{* * *}$ & 0.115 & 0.846 & 0.118 \\
\hline Children in home country & & & & & $2.968^{* * *}$ & 0.488 & $1.477^{* * *}$ & 0.177 \\
\hline Tests of linear hypothesis & & & & & & & & \\
\hline Return estimates $=$ Va-et-vient estimates & & & & & & & & \\
\hline Value; d.f.; prob. & & 61.80; & $3 ; 0.000$ & & & 92.27 & $; 0.000$ & \\
\hline Family location estimates $=0$ & & & & & & & & \\
\hline Value; d.f.; prob. & & & & & & 168.9; & $4 ; 0.000$ & \\
\hline $\begin{array}{l}\text { Family location: Return = Va-et-vient } \\
\text { Value; d.f.; prob. }\end{array}$ & & & & & & 32.4 & 0.000 & \\
\hline Test of $\mathrm{H}_{0}$ : IIA holds (return omitted) & & & & & & & & \\
\hline Value; d.f. ; prob & & -8.99 & $4 ; 1.000$ & & & -1.535 & $1 ; 1.000$ & \\
\hline Pseudo $\mathrm{R}^{2}$ & & & & & & & & \\
\hline Log likelihood & & & & & & & & \\
\hline
\end{tabular}

Survey PRI 2003.

Note : Multinomial Logit models. Levels of significance are respectively equal to $1 \%\left(^{* *}\right), 5 \%\left(^{* *}\right)$ and $10 \%\left(^{*}\right)$. For each specification, the reference alternative is to stay in France. The sample comprises 3915 observations. 
Table 6. MNL models of the impact of children's location

\begin{tabular}{|c|c|c|c|c|}
\hline \multirow[t]{2}{*}{ Specification } & \multicolumn{2}{|c|}{ Return } & \multicolumn{2}{|c|}{ Va-et-vient } \\
\hline & Odd ratio & s.e. & Odd ratio & s.e. \\
\hline $\begin{array}{l}\text { (1) All observation }(N=3915) \\
\text { Control variables: Individual + Country dummies } \\
\text { Family variables: Number of children under } 16 \\
\text { (2) All observation }(N=3915) \\
\text { Control variables: Individual + Country dummies }\end{array}$ & 0.947 & 0.054 & $0.925^{* *}$ & 0.035 \\
\hline $\begin{array}{ll}\text { Family variables: } & \text { Number of children under } 16 \\
& \text { Number of girls under } 16\end{array}$ & $\begin{array}{l}0.881 \\
1.180\end{array}$ & $\begin{array}{l}0.080 \\
0.166\end{array}$ & $\begin{array}{l}0.803^{* * *} \\
1.334^{* * *}\end{array}$ & $\begin{array}{l}0.047 \\
0.118\end{array}$ \\
\hline $\begin{array}{l}\text { (3) All observation }(N=3915) \\
\text { Control variables: Individual + Country dummies }\end{array}$ & & & & \\
\hline $\begin{aligned} \text { Family variables: } & \text { Number of children } \\
& \text { Number of girls }\end{aligned}$ & $\begin{array}{l}1.038 \\
0.968\end{array}$ & $\begin{array}{l}0.061 \\
0.081\end{array}$ & $\begin{array}{l}1.020 \\
1.033\end{array}$ & $\begin{array}{l}0.037 \\
0.052\end{array}$ \\
\hline $\begin{array}{l}\text { (4) All observations }(N=3915) \\
\text { Control variables: Individual + Country dummies }\end{array}$ & & & & \\
\hline $\begin{array}{ll}\text { Family variables: } & \text { Number of children living in France } \\
& \text { Number of girls living in France } \\
& \text { Number of children living in origin country } \\
& \text { Number of girls living in origin country }\end{array}$ & $\begin{array}{c}0.866^{* * *} \\
1.104 \\
1.627^{* * *} \\
0.811\end{array}$ & $\begin{array}{l}0.051 \\
0.091 \\
0.170 \\
0.155\end{array}$ & $\begin{array}{l}0.941^{*} \\
1.092^{*} \\
1.063 \\
1.215\end{array}$ & $\begin{array}{l}0.031 \\
0.050 \\
0.095 \\
0.182\end{array}$ \\
\hline
\end{tabular}

Survey PRI 2003.

Note : Multinomial Logit models. Levels of significance are respectively equal to $1 \%\left({ }^{* *}\right), 5 \%\left(^{* *}\right)$ and $10 \%\left({ }^{*}\right)$. For each specification, the reference alternative is to stay in France. The sample comprises 3915 observations. Other covariates are similar to those of Table 5 , without family location variables. 
Table 7. The impact of the child's location on the parent's location decision

\begin{tabular}{|c|c|c|c|c|c|c|c|c|}
\hline \multirow[b]{2}{*}{ Variables } & \multicolumn{4}{|c|}{$\begin{array}{c}\text { Model 1: } \\
\text { Exogenous child's location }\end{array}$} & \multicolumn{4}{|c|}{$\begin{array}{c}\text { Model 2: } \\
\text { Endogenous child's location }\end{array}$} \\
\hline & \multicolumn{2}{|c|}{ Return } & \multicolumn{2}{|c|}{ Va-et-vient } & \multicolumn{2}{|c|}{ Return } & \multicolumn{2}{|c|}{ Va-et-vient } \\
\hline EQUATION 1 - LOGIT MNL & coef. & s.e. & coef. & s.e. & coef. & s.e. & coef. & s.e. \\
\hline $\begin{array}{l}\text { Constant } \\
\text { Respondent's characteristics }\end{array}$ & 0.202 & 0.532 & $0.532^{*}$ & 0.310 & 0.261 & 0.498 & 0.432 & 0.316 \\
\hline Female & $-0.591^{* * *}$ & 0.080 & $-0.409^{* * *}$ & 0.049 & $-0.664^{* * *}$ & 0.084 & $-0.425^{* * *}$ & 0.050 \\
\hline Age $\left(10^{\mathrm{e}}-2\right)$ & $-2.758^{* * *}$ & 0.798 & $-2.743^{* * *}$ & 0.456 & $-1.963^{* *}$ & 0.801 & $-2.024^{* * *}$ & 0.493 \\
\hline Years since migration $\left(10^{\mathrm{e}}-2\right)$ & $-5.437^{* * *}$ & 0.496 & $-3.019^{* * *}$ & 0.273 & $-5.596^{* * *}$ & 0.498 & $-3.298^{* * *}$ & 0.307 \\
\hline Live in couple & -0.114 & 0.119 & 0.058 & 0.075 & $-0.213^{*}$ & 0.117 & 0.013 & 0.074 \\
\hline Years of education $\left(10^{\mathrm{e}}-2\right)$ & $-2.480^{* * *}$ & 0.790 & $-2.584^{* * *}$ & 0.481 & $-2.840^{* * *}$ & 0.775 & $-2.750^{* * *}$ & 0.481 \\
\hline Household's income (10e-5) & 0.083 & 0.187 & $0.401^{* * *}$ & 0.104 & 0.045 & 0.179 & $0.397^{* * *}$ & 0.087 \\
\hline \multicolumn{9}{|l|}{ Origin country (reference $=$ Northern Europe) } \\
\hline Southern Europe & $1.574^{* * *}$ & 0.265 & $1.363^{* * *}$ & 0.158 & $1.322^{* * *}$ & 0.236 & $1.284^{* * *}$ & 0.155 \\
\hline East Europe & -0.107 & 0.415 & $0.646^{* * *}$ & 0.211 & -0.358 & 0.404 & $0.584^{* * *}$ & 0.208 \\
\hline North Africa & $0.539^{* *}$ & 0.260 & $1.177^{* * *}$ & 0.156 & 0.285 & 0.237 & $1.103^{* * *}$ & 0.153 \\
\hline Middle and South of Africa & $2.011^{* * *}$ & 0.258 & $1.418^{* * *}$ & 0.166 & $1.777^{* * *}$ & 0.234 & $1.333^{* * *}$ & 0.162 \\
\hline America & $1.390^{* * *}$ & 0.332 & $1.153^{* * *}$ & 0.224 & $1.178^{* * *}$ & 0.310 & $1.087^{* * *}$ & 0.221 \\
\hline Middle East & $0.796^{* * *}$ & 0.294 & $1.184^{* * *}$ & 0.175 & 0.434 & 0.273 & $1.105^{* * *}$ & 0.172 \\
\hline Asia & $0.919^{* * *}$ & 0.280 & $0.509^{* * *}$ & 0.185 & $0.563^{* *}$ & 0.259 & $0.415^{* *}$ & 0.180 \\
\hline \multicolumn{9}{|l|}{ Child' location } \\
\hline Child in origin country & $1.365^{* * *}$ & 0.109 & $0.531^{* * *}$ & 0.081 & $1.403^{* * *}$ & 0.369 & -0.226 & 0.234 \\
\hline $\begin{array}{l}\text { EQUATION } 2 \text { - PROBIT } \\
\text { Constant } \\
\text { Child's characteristics }\end{array}$ & & & & & \multicolumn{2}{|c|}{$\begin{array}{c}\text { coef } \\
-2.471^{* * *}\end{array}$} & \multicolumn{2}{|c|}{$\begin{array}{c}\text { s.e. } \\
0.066\end{array}$} \\
\hline Female & & & & & \multicolumn{2}{|c|}{$0.081^{* *}$} & \multicolumn{2}{|c|}{0.038} \\
\hline Age $\left(10^{\mathrm{e}}-2\right)$ & & & & & \multicolumn{2}{|c|}{$0.021^{* * *}$} & \multicolumn{2}{|c|}{0.002} \\
\hline Born in origin country & & & & & 1.20 & & & \\
\hline MNL log likelihood & \multicolumn{4}{|c|}{-9039.4} & \multicolumn{4}{|c|}{-9113.3} \\
\hline
\end{tabular}

Survey PRI 2003.

Note: The first model is a standard MNL model with Huber-White corrected standard errors. The second model is a recursive model with one MNL Logit equation (for the parent's preferred choice of location) and one Probit equation (for the child's actual location). The model is estimated using a two step method, with Murphy-Topel corrected standard errors. Levels of significance are respectively equal to $1 \%\left(^{* *}\right), 5 \%\left(^{* *}\right)$ and $10 \%\left(^{*}\right)$. For each specification, the reference alternative is to stay in France for the MNL model. The sample comprises 11349 child-parent pairs belonging to 3569 families. 
Figure 1. Location intention when retiring, by respondent's age

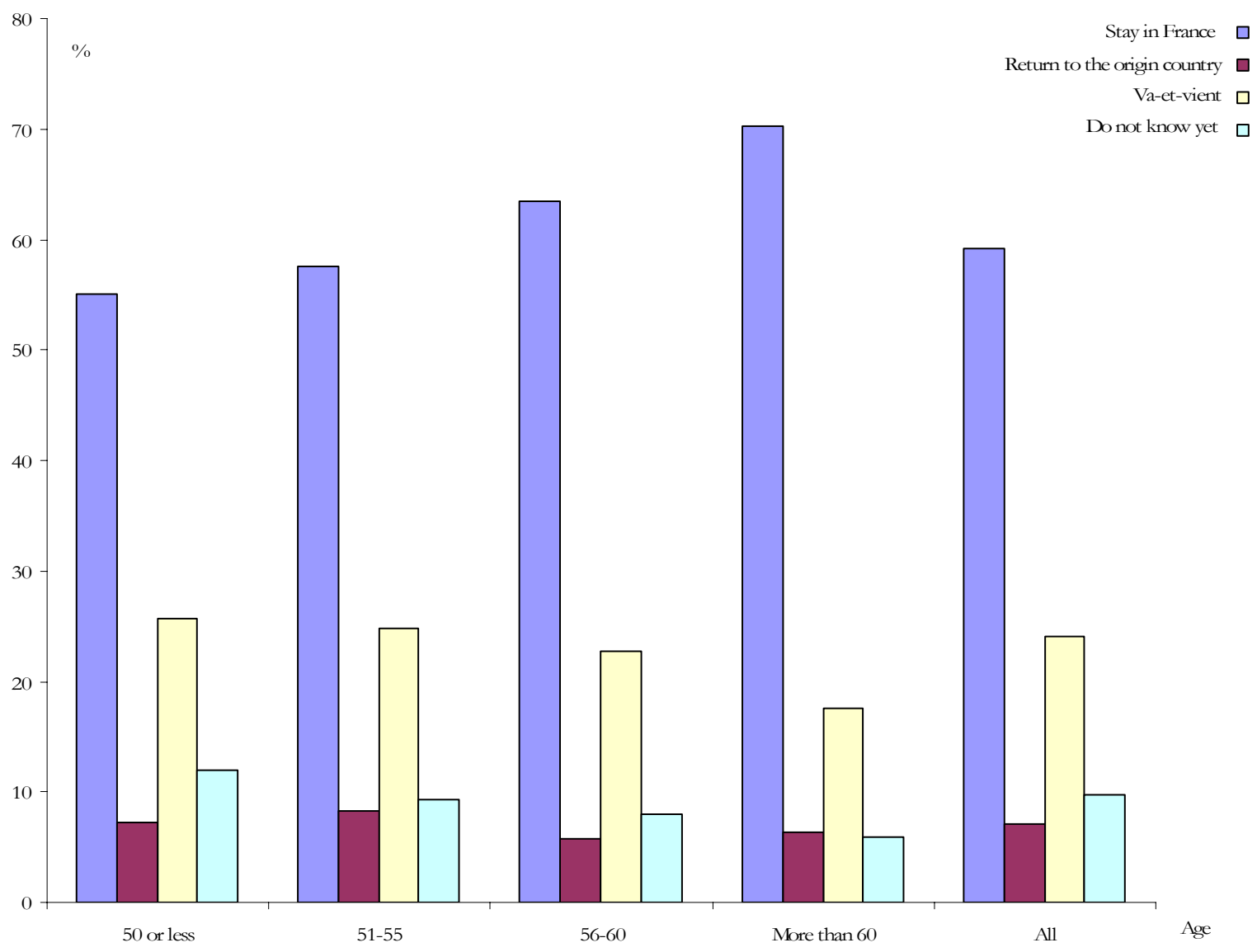

Survey PRI 2003. 